\title{
QUALITY MEASUREMENT OF TRANSPORTATION SERVICE APPLICATION GO-JEK USING ISO 25010 QUALITY MODEL
}

\author{
Millati Izzatillah \\ Faculty of Engineering and Computer Science, Informatics Study Program \\ Universitas Indraprasta PGRI \\ Email: mizzatillah@gmail.com
}

\begin{abstract}
GO-JEK is the most widely used transportation service application by Indonesian society that its users reached $21.6 \%$ of the total users of transportation service application. GO-JEK application has 12 services include many functions that must running well. The services can be ordered by multiple users in the same time. Based on that condition, quality of GO-JEK application need to be measured that all functions running well or not. So, the result will be better application performance using mobile application quality measurement standards ISO 25010 Quality Model. Testing result of all subcharacteristics in ISO 25010 Quality Model, quality of GO-JEK application in Product Quality dimension is $79.30 \%$ on Android device and $80.88 \%$ on iOS device from maximum product quality value of mobile application is $91.37 \%$. While in Quality in Use dimension is $76.22 \%$ from maximum quality in use value of mobile application is $94.75 \%$. These things show GO-JEK application have a good quality in product quality dimension and in quality in use dimension or the user's perspective.
\end{abstract}

Keywords: transportation service application; GO-JEK; ISO 25010; quality model.

\section{INTRODUCTION}

Research results from Indonesia Growth for Knowledge (GfK) stated that mobile apps users are aged between 20 and 40 years of $68 \%$ the Indonesian society population [1]. Mobile based application covers the entire scope of human life, one of them is the transportation. Transportation service application is an application that provides a variety of services to vehicle sharing system at a time and in a short time [2]. Research results from Indonesia Growth for Knowledge (GfK), Robin Muliady said that the transportation service the most widely used application is the GO-JEK followed by Grab, Kereta Api Access, JNE and Uber. GO-JEK application users reached $21.6 \%$ of the total users of transportation service application that used in Indonesia [3].

Use of GO-JEK application has a very high intensity when viewed from the total users. Besides that, GO-JEK also has 12 services include many functions that must running well. The services can be ordered by multiple users in the same time. Based on these conditions quality of GO-JEK application need to be measured that all functions running properly and correctly resulting in better application performance.

Measuring the quality of transportation service GO-JEK application would be measured using ISO 25010 Quality Model. Characteristics to be tested from ISO 25010 Quality Model covers two dimensions, namely the Product quality and Quality in use. ISO 25010 Quality Model have been selected for based research [4] ISO 25010 Quality Model is the latest standard and relevant to test a mobile application replaces the previous standard ISO 9126 Quality Model, which since 2001 become a standard benchmark quality analysis software.

The purpose of this research is to measure the Product Quality and Quality in Use of transportation service application GO-JEK using ISO 25010 Quality Model. Beside that, for proving whether the GOJEK application already fulfil quality standard based on international standardization and see what characteristics influence the application with reference to ISO 25010 Quality Model, which is expected to provide information and guidance for developer in the development of mobile application transportation service.

\section{RESEARCH METHOD}

\subsection{Literature Review}

The following are theories that form the basis for this research.

\subsubsection{Transportation Services Application GO-JEK}


GO-JEK is a company founded by Nadiem Makarim in June 2010. GOJEK is a socially minded technology company that has purpose to improve the welfare of workers in a variety of informal sector in Indonesia. GO-JEK partner about 200.000 motorcycle riders who are experienced and trusted in Indonesia, to provide various services, including transport and home delivery of food. GO-JEK has officially operates in 10 major cities in Indonesia, including Jakarta, Bandung, Bali, Surabaya, Makassar, Yogyakarta, Medan, Semarang, Palembang and Balikpapan with development plans in other cities in the coming year [5].

GO-JEK activity focus on three fundamental values: speed, innovation, and social impact. The GOJEK driver said that their income increased since joining as a partner, they also get health and accident compensation, and gain access to more customers through the application of GO-JEK [5].

\subsubsection{Software Quality Assurance (SQA)}

According to IEEE Glossary, Software Quality Assurance (SQA) a planned and systematic pattern needed to ensure products in accordance with the technical requirements that have been set. Software Quality Assurance (SQA) is also a series of evaluation activities designed to develop or produce a product. SQA is based on the planning and implementation of various actions are integrated into all phases of the software development process. This is done to support the confidence of users that the software product will fulfill all technical requirements [6].

\subsubsection{Quality Models}

Software Quality Assurance (SQA) has several options-quality models that can be used to measure software quality assurance. Typically, software quality have been identified as follows, compliance with specification and user requirement [7]:

Quality models that has international standardization can be trusted reference while measuring software quality. International quality models that often used are McCall's Quality Model (1977), Boehm's Quality Model (1978), and ISO 9126's Quality Model (2001) [7].

\subsubsection{ISO 25010 Quality Models}

ISO 25010 is an extension of ISO 9126. ISO 25010 has two main dimensions: Product Quality and Quality-in-use (QinU). Dimension Product Quality consists of eight quality characteristics, namely Funtional suitability, efficiency Performance, Compatibility, Usability, Reliability, Security, Maintainability and Portability [8]. Comparison of McCall's, Boehm's, ISO 9126 and ISO 25010 quality models based on the characteristics set out in the table 1 .

Tabel 1. Comparison of quality model

\begin{tabular}{cccccc}
\hline No & Faktor Kualitas & $\begin{array}{c}\text { Mc Call } \\
(\text { 1977) }\end{array}$ & Boehm (1978) & $\begin{array}{c}\text { ISO 9126 } \\
(2000)\end{array}$ & $\begin{array}{c}\text { ISO 25010 } \\
\text { (2010) }\end{array}$ \\
\hline 1 & Accuracy & - & - & $\mathrm{X}$ & $\mathrm{X}$ \\
2 & Adaptability & - & - & - & $\mathrm{X}$ \\
3 & Analyzability & - & - & $\mathrm{X}$ & $\mathrm{X}$ \\
4 & Attractiveness & - & - & $\mathrm{X}$ & $\mathrm{X}$ \\
5 & Changeability & - & - & $\mathrm{X}$ & $\mathrm{X}$ \\
6 & Correctness & $\mathrm{X}$ & - & - & $\mathrm{X}$ \\
7 & Efficiency & $\mathrm{X}$ & $\mathrm{X}$ & $\mathrm{X}$ & $\mathrm{X}$ \\
8 & Flexibility & $\mathrm{X}$ & - & - & - \\
9 & Functionality & - & - & $\mathrm{X}$ & $\mathrm{X}$ \\
10 & Human Engineering & - & & - & -
\end{tabular}




\begin{tabular}{|c|c|c|c|c|c|}
\hline No & Faktor Kualitas & $\begin{array}{c}\text { Mc Call } \\
(1977)\end{array}$ & Boehm (1978) & $\begin{array}{c}\text { ISO } 9126 \\
(2000)\end{array}$ & $\begin{array}{c}\text { ISO } 25010 \\
\quad(2010)\end{array}$ \\
\hline 11 & Installability & - & - & $\mathrm{X}$ & $\mathrm{X}$ \\
\hline 12 & Integrity & $\mathrm{X}$ & - & - & $\mathrm{X}$ \\
\hline 13 & Interoperability & $\mathrm{X}$ & - & - & $\mathrm{X}$ \\
\hline 14 & Maintainability & $\mathrm{X}$ & - & $\mathrm{X}$ & $\mathrm{X}$ \\
\hline 15 & Maturity & - & - & $\mathrm{X}$ & $\mathrm{X}$ \\
\hline 16 & Modifiability & - & - & - & $\mathrm{X}$ \\
\hline 17 & Operability & - & - & $\mathrm{X}$ & $\mathrm{X}$ \\
\hline 18 & Performance & - & - & $\mathrm{X}$ & $\mathrm{X}$ \\
\hline 19 & Portability & $\mathrm{X}$ & $\mathrm{X}$ & $X$ & $\mathrm{X}$ \\
\hline 20 & Reliability & $X$ & $X$ & $X$ & $X$ \\
\hline 21 & Resource Utilization & - & - & $\mathrm{X}$ & $\mathrm{X}$ \\
\hline 22 & Reusability & $\mathrm{X}$ & - & - & $\mathrm{X}$ \\
\hline 23 & Stability & - & - & $\mathrm{X}$ & $\mathrm{X}$ \\
\hline 24 & Suitability & - & - & $\mathrm{X}$ & $\mathrm{X}$ \\
\hline 25 & Supportability & - & - & $\mathrm{X}$ & $X$ \\
\hline 26 & Testability & $\mathrm{X}$ & $\mathrm{X}$ & $\mathrm{X}$ & $\mathrm{X}$ \\
\hline 27 & Transferability & - & - & - & $\mathrm{X}$ \\
\hline 28 & Understandability & - & $\mathrm{X}$ & $X$ & $X$ \\
\hline 29 & Usability & $X$ & - & $\mathrm{X}$ & $X$ \\
\hline
\end{tabular}

Based on Table 2.5 ISO 25010 Quality Model has the most complete characteristics than the other quality models because there are 26 of the 28 factors. From this comparison, efficiency, portability and reliability are characteristics of the quality that appears in all models. ISO 25010 Quality Model is a improvement of the ISO 9126 Quality Model.

The new characteristics have been included in ISO 25010 is security and compatibility. Both of these characteristics are not presented in ISO 9126. Beside that, hierarchy of characteristics and sub characteristics in restructure with the purpose to improve the understanding of related concepts. This is done to overcome the limitations of ISO 9126 in connection with the generic nature, incompleteness and vagueness as described by researcher [9].

\subsection{Research Object}

Object used in this research is the most populer transportation service application in Indonesia, GOJEK. Measuring the quality of GO-JEK application will use version 2.5 in the last update on August 30, 2016. In this version, GO-JEK home screen has user interface that is easy to access all the services GOJEK. For service GORIDE, GO-FOOD and GO-MART was renewed appearance. GO-TIX introduce event categories with better discovery features and hot deals. GO-JEK has provided a feature GO-PAY, so users can easily perform non-cash payment for all services GO-JEK with the top up at an ATM, the MBanking or Internet Banking BCA, BRI, Mandiri, CIMB Niaga and Prima Network. Beside that, GO-JEK 
provide new services that GO-CAR where users can book a private car is the same function as the GORIDE[10].

Calculation of total GO-JEK users in Indonesia (12.090.218 Million) can be a population size that will be used to determine the number of samples. The sample is required to be respondents who will fill out a questionnaire quality of transportation service application GO-JEK to the characteristics Usability in Product Quality dimension and all the characteristics in Quality In Use dimension. Determination of the number of these samples using the formula size Slovin by the following equation:

$$
n=\frac{N}{\left(N+\alpha^{2}\right)+1}=\frac{12,090,218}{\left(12,090,218+(0.1)^{2}\right)+1}=99,99917289 \approx 100
$$

Sample size calculation with Slovin formula obtained 100 respondents who are have Information Technology educational background and domicile in Jakarta and surrounding areas (Depok, Tangerang, Bekasi) with a confidence level of $90 \%$.

\subsection{Data Collecting Method}

Literature Study used to obtain relative weighting characteristics and sub characteristics in ISO 25010 Quality Model using Luis Ricardo CORRAL VELÁZQUEZ research [11] in his dissertation entitled "A Software Assurance Model for Mobile Application".

Observations on this research used to test the quality of a transportation service application on characteristics Functional Suitability, Performance Efficiency, Reliability, Compatibility and Security. The observations were made by author to directly observe the application to be tested by creating a test case for each sub characteristics on ISO 25010 Quality Model using black box testing.

A questionnaire used to measure the characteristics Usability on Product Quality dimension and all characteristics on Quality in Use such as Satisfaction, Effectiveness, Freedom from risk, Efficiency, and Context coverage. Dissemination of questionnaire was conducted online using google form and take the respondents as many as 100 people from Jakarta, Depok, Tangerang and Bekasi. The questionnaire in this research adopts USE Qestionnaire of Lund, A.M. (2001) with a measurement scale for alternative answers using a Likert scale.

\subsection{Methodology}

Testing the quality of transportation service application GO-JEK has several steps that must be done. Stages are included in Figure 1 As follows. 


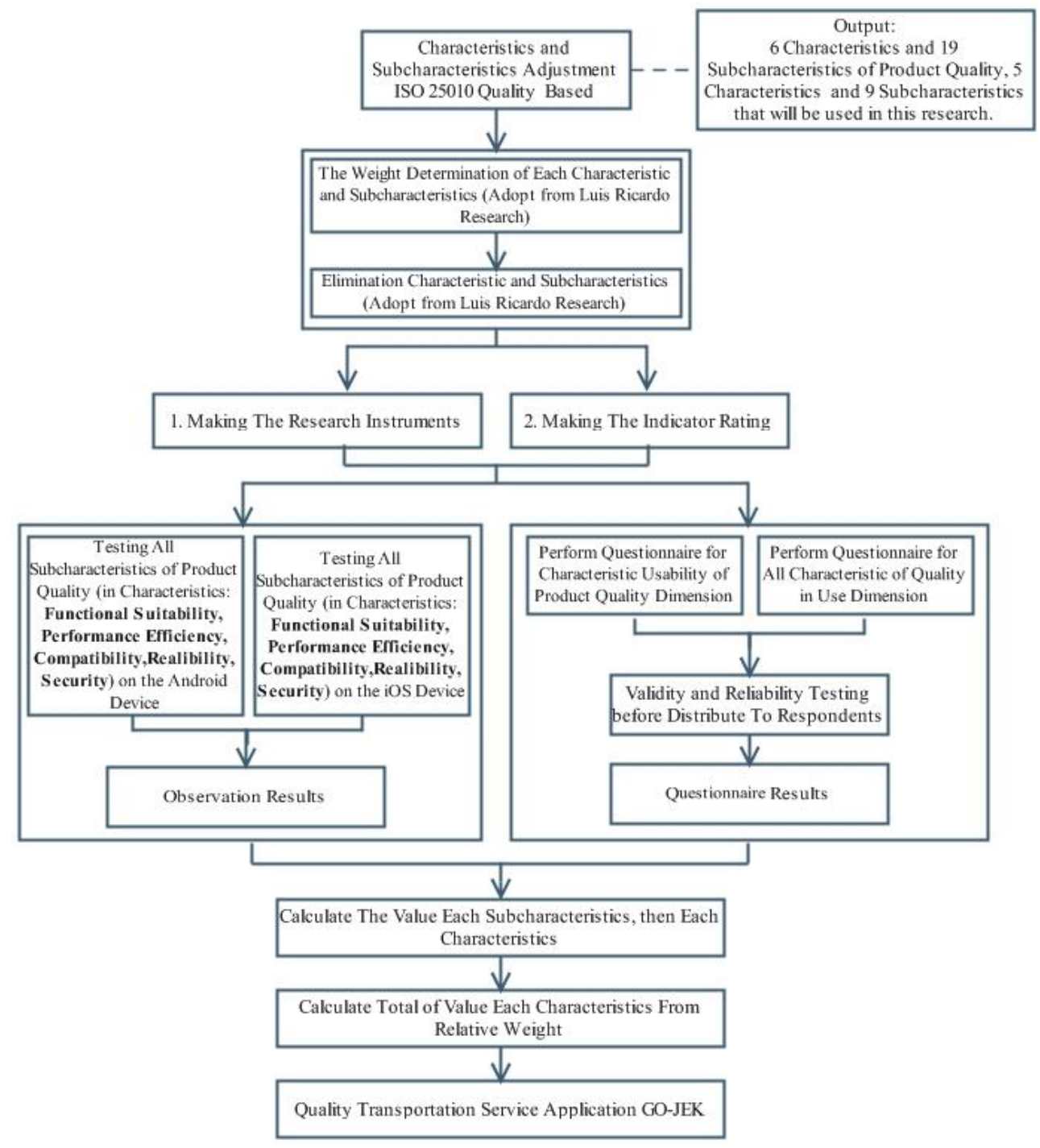

I

Figure 1. Methodology

n figure 1, there are methodology for testing the quality of transportation service application GOJEK. First step is making the research instruments by process characteristic determination and elimination. The next step is making the indicator rating. After that step, obeservation result and questionaire result will be used in calculating the value for each characteristic from relative weight.

\section{RESULT AND DISCUSSION}

\subsection{Respondent Characteristics}

Based on the results of questionnaires, the respondent data obtained by 100 respondents in accordance with the sample size calculation formula slovin and standard error of 0.1 or $10 \%$. Questionnaires were distributed from 13 July 2016 to 110 respondents and filled in 102 questionnaires. Respondents are users of the application GO-JEK and have information technology educational background. Respondents data obtained in this research questionnaire form the characteristics of respondents. Respondents characteristics in this research include aspect of gender, age, current residence (domicile), and profession. The following table shows the percentage of respondents characteristics.

Tabel 2. Respondent characteristics

\begin{tabular}{cccc}
\hline & Respondent Characteristics & Frequency & Percentage \\
\hline \multirow{4}{*}{ Gender } & Male & 54 & $54 \%$ \\
& $100 \%$ & & \\
& Female & 46 & $46 \%$ \\
& Total & 100 & $100 \%$ \\
\hline
\end{tabular}




\begin{tabular}{clcc}
\hline & Respondent Characteristics & Frequency & Percentage \\
\hline \multirow{6}{*}{ Age } & 2 20 & 5 & $5 \%$ \\
& $20-24$ & 85 & $85 \%$ \\
& $25-29$ & 9 & $9 \%$ \\
& $>30$ & 1 & $1 \%$ \\
& Total & 100 & $100 \%$ \\
& IT Staff & 23 & $23 \%$ \\
& IT Support & 13 & $13 \%$ \\
& Developer & 13 & $13 \%$ \\
& IT Lecturer & 3 & $3 \%$ \\
Profession & College Student Majoring IT & 28 & $28 \%$ \\
& Fresh Graduate Majoring IT & 20 & $20 \%$ \\
& Total & 100 & $100 \%$ \\
& South Jakarta & 17 & $17 \%$ \\
& East Jakarta & 12 & $12 \%$ \\
& Central Jakarta & 8 & $8 \%$ \\
& West Jakarta & 2 & $2 \%$ \\
& North Jakarta & 1 & $1 \%$ \\
Domicile & Depok & 35 & $35 \%$ \\
& Tangerang & 9 & $9 \%$ \\
& Bekasi & 16 & $16 \%$ \\
& Total & 100 & $100 \%$ \\
& 2013 & 1 & $1 \%$ \\
& 2014 & 5 & $5 \%$ \\
Start Using & 2015 & 63 & $63 \%$ \\
& 2016 & 31 & $31 \%$ \\
& Total & 100 & $100 \%$ \\
\hline \multirow{6}{*}{} & &
\end{tabular}

\subsection{Testing Result of Transportation Service Application GO-JEK}

Transportation service application GO-JEK tested every characteristic in ISO 25010 Quality Model to obtain quantitative quality value. Researcher tested GO-JEK application with a mobile device type Sony Experia SP for operating system Android and Iphone $5 \mathrm{~s}$ for operating system IOS.

Each score calculation of each characteristic and sub characteristics of ISO 25010 on the dimensions of Product Quality and Quality in Use has been successfully carried out on a transportation service application GO-JEK. After that value sub characteristics by observation or questionnaire results shown by the level of the indicator, the level value calculated by weighting sub characteristic to see whether the calculation result is equal to or lower weight than the relatives weight. The result of the calculation of product quality on the android device is described in the following table.

Tabel 3. Product quality testing result on android device

\begin{tabular}{|c|c|c|c|c|c|c|}
\hline Characteristics & $\begin{array}{l}\text { Relative } \\
\text { Weight }\end{array}$ & Sub characteristics & $\begin{array}{c}\text { Relative } \\
\text { Weight } \\
\text { per sub } \\
\text { char } \\
(W n)\end{array}$ & $\begin{array}{c}\text { Level } \\
(\text { Ln) }\end{array}$ & $\begin{array}{c}\text { Value } \\
\text { Subchar } \\
\text { (valueSCn) }\end{array}$ & $\begin{array}{c}\text { Value } \\
\text { char } \\
\text { (valueCn) }\end{array}$ \\
\hline 1. & & 1.1 Functional Completeness & $6.18 \%$ & 5 & $6.18 \%$ & \\
\hline Functional & $20.72 \%$ & 1.2 Functional Correctness & $6.32 \%$ & 5 & $6.32 \%$ & $20.72 \%$ \\
\hline Suitability & & $\begin{array}{l}1.3 \text { Functional } \\
\text { Appropriateness }\end{array}$ & $8.22 \%$ & 5 & $8.22 \%$ & \\
\hline 2. Performance & & 2.1 Time Behavior & $3.36 \%$ & 4 & $2.68 \%$ & \\
\hline Efficiency & $12.57 \%$ & $\begin{array}{l}\text { 2.2 Resource Utilization } \\
\text { 2.3 Capacity }\end{array}$ & $\begin{array}{l}5.70 \% \\
3.51 \%\end{array}$ & $\begin{array}{l}4 \\
5\end{array}$ & $\begin{array}{l}4.56 \% \\
3.51 \%\end{array}$ & $12.57 \%$ \\
\hline $\begin{array}{l}3 . \\
\text { Compatibility }\end{array}$ & $5.12 \%$ & $\begin{array}{l}\text { 3.1 Co-existence } \\
\text { 3.2 Interoperability } \\
\text { 4.1 Appropriateness }\end{array}$ & $\begin{array}{l}2.60 \% \\
2.52 \% \\
7.42 \%\end{array}$ & $\begin{array}{l}5 \\
4 \\
4\end{array}$ & $\begin{array}{l}2.60 \% \\
2.02 \% \\
5.94 \%\end{array}$ & $4.62 \%$ \\
\hline $\begin{array}{l}\text { 4. Usability } \\
\text { Un }\end{array}$ & $23.10 \%$ & $\begin{array}{l}\text { Recognizability } \\
\text { 4.2 Learnability } \\
\text { 4.3 Operability }\end{array}$ & $\begin{array}{l}3.07 \% \\
4.75 \% \\
\end{array}$ & $\begin{array}{l}4 \\
4 \\
\end{array}$ & $\begin{array}{l}2.45 \% \\
3.80 \% \\
\end{array}$ & $18.48 \%$ \\
\hline
\end{tabular}




\begin{tabular}{|c|c|c|c|c|c|c|}
\hline Characteristics & $\begin{array}{c}\text { Relative } \\
\text { Weight }\end{array}$ & Sub characteristics & $\begin{array}{c}\text { Relative } \\
\text { Weight } \\
\text { per sub } \\
\text { char } \\
\text { (Wn) }\end{array}$ & $\begin{array}{l}\text { Level } \\
(\text { Ln) }\end{array}$ & $\begin{array}{c}\text { Value } \\
\text { Subchar } \\
\text { (valueSCn) }\end{array}$ & $\begin{array}{c}\text { Value } \\
\text { char } \\
\text { (valueCn) }\end{array}$ \\
\hline \multirow{4}{*}{ 5. Reliability } & & 4.5 User Interface Aesthetics & $5.59 \%$ & 4 & $4.47 \%$ & \\
\hline & & 4.6 Accessability & $2.27 \%$ & 4 & $1.82 \%$ & \\
\hline & $3.33 \%$ & 5.1 Maturity & $3.33 \%$ & 4 & $2.66 \%$ & \multirow[t]{2}{*}{$2.66 \%$} \\
\hline & & 6.1 Confidentiality & $4.28 \%$ & 5 & $4.28 \%$ & \\
\hline 6. & & 6.2 Integrity & $4.46 \%$ & 4 & $3.56 \%$ & \multirow{4}{*}{$22.07 \%$} \\
\hline \multirow{3}{*}{ Security } & $26.53 \%$ & 6.3 Nonrepudiation & $8.00 \%$ & 4 & $6.4 \%$ & \\
\hline & & 6.4 Accountability & $6.14 \%$ & 4 & $4.91 \%$ & \\
\hline & & 6.5 Authenticity & $3.65 \%$ & 4 & $2.92 \%$ & \\
\hline Sum of & \multicolumn{6}{|c|}{ Product Quality Testing Result on Android Device } \\
\hline $\begin{array}{c}\text { Total } \\
\text { Weights }\end{array}$ & $91.37 \%$ & & & & & $79.30 \%$ \\
\hline
\end{tabular}

Table 3. shows that the quality of service application transportation GO-JEK on Product Quality dimension on android device is $79.30 \%$. These results indicate that the quality of the GO-JEK, $12.07 \%$ below the maximum weight value quality mobile applications is $91.37 \%$. Overall quality of the application GO-JEK are at level 4 and 5. This shows the quality of the application GO-JEK dimensions of product quality are tested on android devices already good. Besides tested on android devices, applications GO-JEK tested on iOS devices. The result of the calculation of product quality on the iOS device is described in the following table

Tabel 4. Product quality testing result on IOS device

\begin{tabular}{|c|c|c|c|c|c|c|}
\hline Characteristics & $\begin{array}{c}\text { Relative } \\
\text { Weight }\end{array}$ & Sub characteristics & $\begin{array}{c}\text { Relative } \\
\text { Weight } \\
\text { per sub } \\
\text { char } \\
\text { (Wn) }\end{array}$ & $\begin{array}{c}\text { Level } \\
\text { (Ln) }\end{array}$ & $\begin{array}{c}\text { Value } \\
\text { Subchar } \\
\text { (valueSCn) }\end{array}$ & $\begin{array}{c}\text { Value } \\
\text { char } \\
\text { (valueCn) }\end{array}$ \\
\hline \multirow{4}{*}{$\begin{array}{l}\text { 1.Functional } \\
\text { Suitability }\end{array}$} & \multirow[t]{4}{*}{$20.72 \%$} & 1.1 Functional & $6.18 \%$ & 5 & $6.18 \%$ & \multirow{4}{*}{$20.72 \%$} \\
\hline & & Completeness & & & & \\
\hline & & 1.2 Functional Correctness & $6.32 \%$ & 5 & $6.32 \%$ & \\
\hline & & $\begin{array}{l}\text { 1.3 Functional } \\
\text { Appropriateness }\end{array}$ & $8.22 \%$ & 5 & $8.22 \%$ & \\
\hline \multirow{3}{*}{$\begin{array}{l}\text { 2. Performance } \\
\text { Efficiency }\end{array}$} & \multirow[t]{3}{*}{$12.57 \%$} & 2.1 Time Behavior & $3.36 \%$ & 5 & $3.36 \%$ & \multirow{3}{*}{$11.43 \%$} \\
\hline & & 2.2 Resource Utilization & $5.70 \%$ & 4 & $4.56 \%$ & \\
\hline & & 2.3 Capacity & $3.51 \%$ & 5 & $3.51 \%$ & \\
\hline \multirow[t]{3}{*}{ 3.Compatibility } & $5.12 \%$ & 3.1 Co-existence & $2.60 \%$ & 5 & $2.60 \%$ & \multirow[t]{3}{*}{$4.62 \%$} \\
\hline & & 3.2 Interoperability & $2.52 \%$ & 4 & $2.02 \%$ & \\
\hline & & 4.1 Appropriateness & $7.42 \%$ & 4 & $5.94 \%$ & \\
\hline \multirow[t]{6}{*}{ 4.Usability } & $23.10 \%$ & Recognizability & & & & \multirow{6}{*}{$18.48 \%$} \\
\hline & & 4.2 Learnability & $3.07 \%$ & 4 & $2.45 \%$ & \\
\hline & & 4.3 Operability & $4.75 \%$ & 4 & $3.80 \%$ & \\
\hline & & 4.5 User Interface & $5.59 \%$ & 4 & $4.47 \%$ & \\
\hline & & Aesthetics & & & & \\
\hline & & 4.6 Accessability & $2.27 \%$ & 4 & $1.82 \%$ & \\
\hline \multirow[t]{2}{*}{ 5. Reliability } & $3.33 \%$ & 5.1 Maturity & $3.33 \%$ & 4 & $2.66 \%$ & \multirow[t]{2}{*}{$2.66 \%$} \\
\hline & & 6.1 Confidentiality & $4.28 \%$ & 5 & $4.28 \%$ & \\
\hline \multirow[t]{4}{*}{ 6. Security } & $26.53 \%$ & 6.2 Integrity & $4.46 \%$ & 5 & $4.46 \%$ & \multirow{4}{*}{$22.97 \%$} \\
\hline & & 6.3 Nonrepudiation & $8.00 \%$ & 4 & $6.4 \%$ & \\
\hline & & 6.4 Accountability & $6.14 \%$ & 4 & $4.91 \%$ & \\
\hline & & 6.5 Authenticity & $3.65 \%$ & 4 & $2.92 \%$ & \\
\hline $\begin{array}{l}\text { Sum of } \\
\text { Total } \\
\text { Weights }\end{array}$ & \multicolumn{6}{|c|}{ Product Quality Testing Result on iOS Device } \\
\hline
\end{tabular}

Table 4. shows that the quality of service application transportation GO-JEK on Product Quality dimension on $\mathrm{iOS}$ devices is $80.88 \%$. These results indicate that the quality of the GO-JEK, $10.49 \%$ 
below the maximumweight value quality mobile applications is $91.37 \%$. Overall quality of the application GO-JEK are at level 4 and 5. This shows the quality of the application GO-JEK dimensions of product quality is tested on iOS devices has been good.

On the product quality dimension testing on the device operating system android and iOS, while the dimensions of Quality in Use is done with a questionnaire for Quality in Use is a quality application assessed from user's perspective. The following table is the result of the calculation on the quality dimension of Quality in Use.

Tabel 5. Quality in use testing result

\begin{tabular}{|c|c|c|c|c|c|c|}
\hline Characteristics & $\begin{array}{r}\text { Relative } \\
\text { Weight }\end{array}$ & Sub characteristics & $\begin{array}{c}\text { Relative } \\
\text { Weight } \\
\text { per sub } \\
\text { char } \\
\text { (Wn) }\end{array}$ & $\begin{array}{c}\text { Leve } \\
\quad l \\
(L n)\end{array}$ & $\begin{array}{c}\text { Value } \\
\text { Subchar } \\
\text { (valueSCn } \\
\text { ) }\end{array}$ & $\begin{array}{c}\text { Value } \\
\text { char } \\
\text { (valueCn } \\
\quad \text { ) }\end{array}$ \\
\hline 1. Effectiveness & $9.54 \%$ & 1. Effectiveness & $9.54 \%$ & 4 & $7.63 \%$ & $7.63 \%$ \\
\hline 2. Efficiency & $9.54 \%$ & $\begin{array}{l}\text { 2. Efficiency } \\
\text { 3.1 Usefulness }\end{array}$ & $\begin{array}{l}9.54 \% \\
10.15 \%\end{array}$ & $\begin{array}{l}4 \\
4\end{array}$ & $\begin{array}{l}7.63 \% \\
8.12 \%\end{array}$ & $7.63 \%$ \\
\hline $\begin{array}{l}3 . \\
\text { Satisfaction }\end{array}$ & $47.52 \%$ & $\begin{array}{l}\text { 3.2 Trust } \\
\text { 3.3 Pleasure } \\
\text { 3.4 Comfort }\end{array}$ & $\begin{array}{l}15.70 \% \\
11.61 \% \\
10.06 \%\end{array}$ & $\begin{array}{l}4 \\
4 \\
4\end{array}$ & $\begin{array}{l}12.56 \% \\
9.28 \% \\
8.48 \%\end{array}$ & $38.44 \%$ \\
\hline $\begin{array}{l}4 . \\
\text { Freedom } \\
\text { from risk }\end{array}$ & $16.64 \%$ & $\begin{array}{l}\text { 4.1 Economic risk } \\
\text { mitigation } \\
4.2 \text { Health and safety } \\
\text { Risk mitigation }\end{array}$ & $\begin{array}{l}8.60 \% \\
8.04 \%\end{array}$ & 4 & $\begin{array}{l}6.88 \% \\
6.43 \%\end{array}$ & $22.52 \%$ \\
\hline $\begin{array}{l}\text { 5. Context } \\
\text { Coverage }\end{array}$ & $11.51 \%$ & $\begin{array}{l}5.1 \text { Context } \\
\text { Completeness }\end{array}$ & $11.51 \%$ & 4 & $9.21 \%$ & $9.21 \%$ \\
\hline $\begin{array}{c}\text { Sum of } \\
\text { Total } \\
\text { Weights }\end{array}$ & $94.75 \%$ & \multicolumn{4}{|c|}{ Quality in Use Testing Result } & $76.22 \%$ \\
\hline
\end{tabular}

Table 5 shows that the quality of transportation service application GO-JEK on the Quality in Use dimension is $76.22 \%$. The results of the weight difference of dimensions of quality in use $18.53 \%$ from maximum for quality mobile applications. Overall, quality transportation service application GOJEK has been good from the perspective of the user, for each characteristic is at level 4.

Furthermore, researcher will describe results of quality on every sub characteristic using priority rangking table. This is done to ensure the criteria in the transportation service application GO-JEK fulfil the quality characteristics of the weights based on the relatives weight of ranking the priority Product Quality and Quality in Use. Here is a table with results ranking priority measurement quality on Product Quality dimension.

Tabel 6. Priority ranking result of product quality dimension

\begin{tabular}{llcccc}
\hline No & \multicolumn{1}{c}{ Subcharacteristics } & Ranking & Relative Weight & ResultAndroid & Result iOS \\
\hline 1.3 & Functional Appropriateness & 1 & $8.22 \%$ & $8.22 \%$ & $8.22 \%$ \\
6.3 & Non Repudiation & 2 & $8.00 \%$ & $6.4 \%$ & $6.4 \%$ \\
4.1 & Appropriateness Recognizability & 3 & $7.42 \%$ & $5.94 \%$ & $5.94 \%$ \\
1.2 & Functional Correctness & 4 & $6.32 \%$ & $6.32 \%$ & $6.32 \%$ \\
1.1 & Functional Completeness & 5 & $6.18 \%$ & $6.18 \%$ & $6.18 \%$ \\
6.4 & Accountability & 6 & $6.11 \%$ & $4.91 \%$ & $4.91 \%$ \\
2.2 & Resource Utilization & 7 & $5.70 \%$ & $4.56 \%$ & $4.56 \%$ \\
4.5 & User Interface Aesthetics & 8 & $5.59 \%$ & $4.47 \%$ & $4.47 \%$ \\
4.3 & Operability & 9 & $4.75 \%$ & $3.80 \%$ & $4.75 \%$ \\
6.2 & Integrity & 10 & $4.46 \%$ & $3.56 \%$ & $4.46 \%$ \\
6.1 & Confidentially & 11 & $4.28 \%$ & $4.28 \%$ & $4.28 \%$ \\
6.5 & Authenticity & 12 & $3.65 \%$ & $2.92 \%$ & $2.92 \%$ \\
2.3 & Capacity & 13 & $3.51 \%$ & $3.51 \%$ & $3.51 \%$ \\
2.1 & Time Behaviour & 14 & $3.36 \%$ & $2.68 \%$ & $3.36 \%$ \\
5.1 & Maturity & 15 & $3.33 \%$ & $2.66 \%$ & $2.66 \%$ \\
4.2 & Learnability & 16 & $3.07 \%$ & $2.45 \%$ & $2.45 \%$ \\
3.1 & Co-existence & 17 & $2.60 \%$ & $2.60 \%$ & $2.60 \%$ \\
3.2 & Interoperability & 18 & $2.52 \%$ & $2.02 \%$ & $2.02 \%$ \\
4.6 & Accessibility & 19 & $2.27 \%$ & $1.82 \%$ & $1.82 \%$ \\
& Sum of Weight Total & & $91.37 \%$ & $79.30 \%$ & $80.88 \%$ \\
\hline
\end{tabular}


Table 6. shows that the transportation service application GO-JEK fulfil the criteria of the most important characteristics that should be required with the percentage of each sub characteristics quality in accordance with the percentage of properly. As for the dimensions of quality in use, with a priority ranking table measurement quality results in the following table.

Tabel 7. Priority ranking of relative weight quality in use dimension

\begin{tabular}{llccc}
\hline No & \multicolumn{1}{c}{ Subcharacteristics } & Ranking & Relative Weight & Result \\
\hline 3.2 & Trust & 1 & $15.70 \%$ & $12.56 \%$ \\
3.3 & Pleasure & 2 & $11.61 \%$ & $9.28 \%$ \\
5.1 & Context Completeness & 3 & $11.51 \%$ & $9.21 \%$ \\
3.1 & Usefulness & 4 & $10.15 \%$ & $8.12 \%$ \\
3.4 & Comfort & 5 & $10.06 \%$ & $8.48 \%$ \\
2 & Efficiency & 6 & $9.54 \%$ & $7.63 \%$ \\
1 & Effectiveness & 7 & $9.54 \%$ & $7.63 \%$ \\
4.1 & Economic Risk Mitigation & 8 & $8.60 \%$ & $6.88 \%$ \\
4.2 & Health and Safety Risk Mitigation & 9 & $8.04 \%$ & $6.43 \%$ \\
\multicolumn{2}{r}{ Sum of Weight Total } & & $94.75 \%$ & $76.22 \%$ \\
\hline
\end{tabular}

Table 7. shows the transportation service application GO-JEK sufficient to fulfil the most important criteria needed by the mobile application on the Quality in Use dimension, it is because the overall percentage result under its relative weight.

Quality transportation service application GO-JEK has been obtained through the results of the percentage of tests that have been carried out. The final result can also be seen in the chart. Here is a chart for the dimensions of product quality.

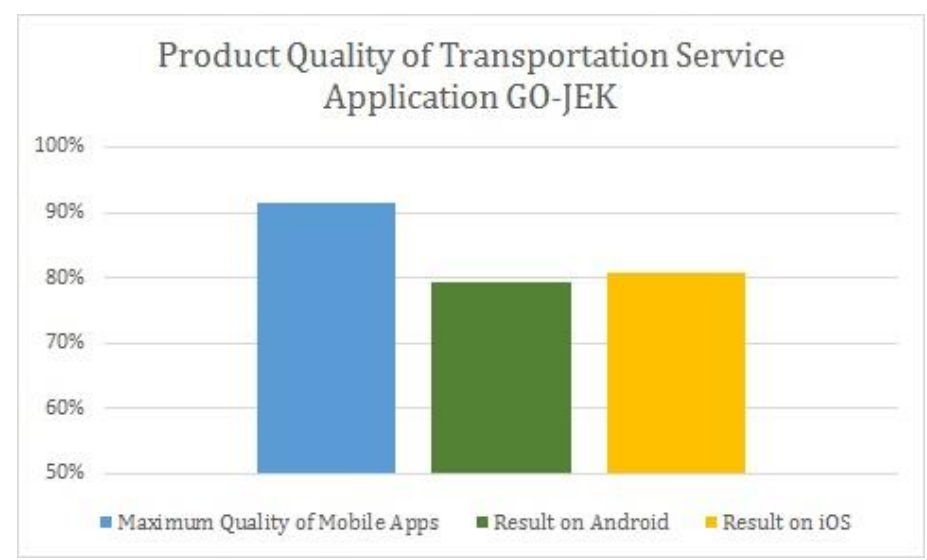

Figure 2. Product Quality of Transportation Service Application GO-JEK

In figure 2, the result of product quality of transportation service application GO-JEK is better used in IOS device than Android device caused Result from the testing on IOS device has more precentage that near by maximum quality of mobile application. While the following is a chart for the dimensions of quality in use.

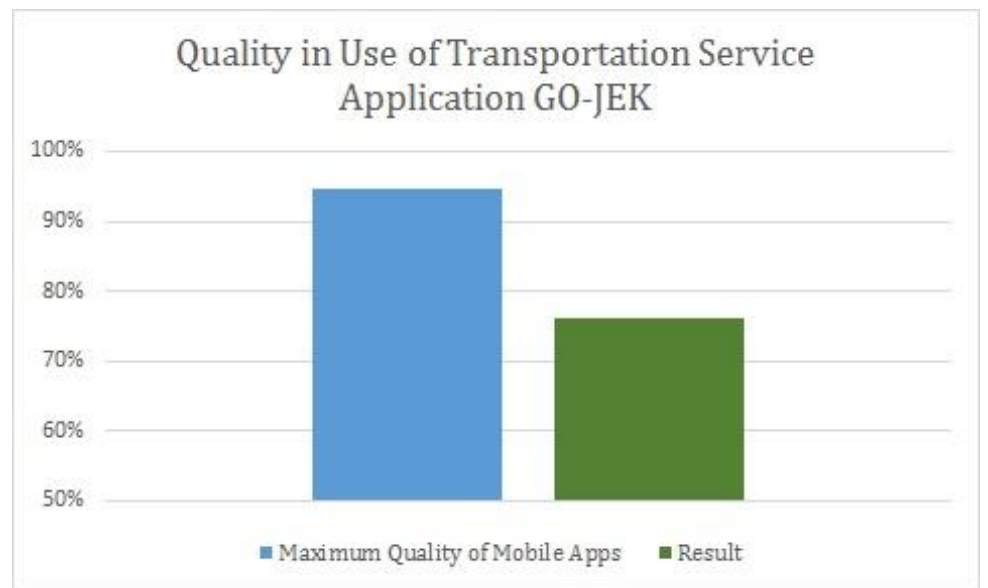

Figure 3. Quality in Use of Transportation Service Application GO-JEK 
In figure 3, there are the result of quality in use dimension of transportation service application GOJEK. The result shows quality in use more than a half presentage from maximum quality of mobile application, that is mean transportation service application GO-JEK is good enough to be used.

\section{CONCLUSION}

Measuring the quality of trasnportation service application GO-JEK using ISO 25010 Quality Model has been successfully carried out by the methods that have been determined. Overall, the GO-JEK application obtain the value of good quality with a percentage on product dimensional quality is equal to $79.30 \%$ on a android device and on iOS devices $80.88 \%$ of the maximum value of mobile application quality by $91.37 \%$. This shows the application GO-JEK have good quality in terms of functional, performance, compatibility, usability, reliability and security. GO-JEK quality of applications in the operating system iOS has a value of higher quality than the android operating system for iOS for some sub characteristic are at a higher level than the android. Subcharacteristic is Operability, Integrity and time behavior. This indicates that the quality of the GO-JEK better on iOS devices to provide ease of operation, preventing the access rights and response time. On the Quality in Use dimension, the quality of trasnportation service application GO-JEK is $76.22 \%$ of the maximum value of mobile application quality is $94.75 \%$. The results of the weight difference of Quality in Usedimension and maximum of quality mobile applications is $18.53 \%$. Overall, quality transportation service application GO-JEK has been good from the user's perspective, for each characteristic is at level 4 is the predicate goo quality.

Measuring the quality of trasnportation service GO-JEK using ISO 25010 Quality Model is open to be developed. Measuring the quality of service application trasnportation GO-JEK needs to be done with various types of testing that is more diverse and need to use tools for multiple characteristics on dimensions of product quality, so we get more accurate results. In addition to filling out the questionnaire on usability characteristics and dimensions of quality in use need to be spread area in the Indonesian region that has been reached by the application GO-JEK.

\section{REFERENCES}

[1] (2016). Mobile apps market study. http://arenalte.com/berita/industri/ini-dia-aplikasi-dan-gamesmobilepaling-populer-di-indonesia/ Accessed on 18th of June 2016.

[2] Andrew Amey, J. A. and Mishalani, R. (2010). Real-time ridesharing: The opportunities and challenges of utilizing mobile phone technology to improve rideshare services.

[3] Ngazis, A. N. and Angelia, M. (2016). Go-jek ungguli grab. http://teknologi.news.viva.co.id/news/read/748464-survei-gojek ungguli grab. Accessed on 14th of June 2016.

[4] Veenendaal, E. v. (2014). The new standard for software product quality testing experience.

[5] (2014). Go-jek. http://www.go-jek.com/ Accessed on 16th of May 2016.

[6] Galin, D. (2004). Software Quality Assurance from Theory to Implementation, $5^{\text {th }}$ ed. England: Pearson Education Limited.

[7] Milicic, D. (2005). Software quality models and philosophies. In Software Quality Attributes and Trade-Offs, volume pp. 3-13. Blekinge Institute of Technology.

[8] ISO/IEC (Switzerland, 2011a). Iso/iec 25000:2014, guide to square. Software and system engineering-Software product Quality Requirements and Evaluation (SQuaRE), 214AD.

[9] Al-Kilidar, H. and Kitchenham, B. (2005). The use and usefulness of the iso/iec 9126 quality standard. In In International Symposium on Empirical Software Engineering.

[10] (2016). What's new on go-jek. https://play.google.com/store/apps/details?id=com. gojek. Accessed on 3rd of September 2016.

[11] Velázquez, L. R. C. (2014). A Software Assurance Model for Mobile Applications. PhD thesis, University of Bozen · Bolzano. 